\title{
Creatine kinase activity in sickle cell disease
}

\author{
BEVERLEY J HUNT, P KORSAH, SUSAN EATON, * MILICA BROZOVIC \\ From the Departments of Haematology and *Chemical Pathology, The Central Middlesex Hospital, London
}

SUMMARY Creatine kinase activity was measured in 28 patients in the steady state of sickle cell disease and ranged from $4-45 \mathrm{IU} / 1$, comparable with that found in healthy adult caucasians. Creatine kinase activity was also measured in 14 patients admitted consecutively for the treatment of vasoocclusive sickle cell crises. Creatine kinase activity remained within the normal range in eight of these 14 patients throughout their admission; none had muscle pain or a chest syndrome. In the remaining six, three with muscle pain and three with a chest syndrome, increased activity was found on one or more days. A further 17 patients with vaso-occlusive sickle cell crises, associated with muscle pain, were studied. Creatine kinase activity was significantly raised in all 17, the mean creatine kinase activity for men was $578.8 \mathrm{IU} / 1$ and $210.6 \mathrm{IU} / 1$ for women, with the highest values (up to $1790 \mathrm{IU} / \mathrm{l}$ ) found in those who had exercised before admission.

Measurement of creatine kinase activity may therefore be a useful marker of muscle perturbation due to sickling.

Serum creatine kinase activity is a sensitive index of the membrane permeability of tissues containing creatine kinase. The enzyme is present in the brain, skeletal, and cardiac muscles, and so increased serum creatine kinase activity usually reflects either hypoxic or metabolic damage of these tissues. Severe muscle necrosis produces greatly increased creatine kinase activity and rhabdomyolysis, resulting in free plasma myoglobin with consequent metabolic changes, myoglobinuria, and often, renal failure.

Devereux et al reported one case of rhabdomyolysis and renal failure in a young man with sickle cell disease and a salmonella septicaemia. ${ }^{1}$ Apart from this, there have been no other studies of creatine kinase activity in any aspect of sickle cell disease. In some sickle cell crises muscular pain is the prominent symptom and is often associated with swelling and tenderness of the muscle itself; creatine kinase activity may therefore be predicted to be increased.

The aim of this study was to assess creatine kinase activity in sickle cell disease, both in the steady state and in acute vaso-occlusive crises, especially those involving painful muscles.

Accepted for publication 16 February 1989

\section{Material and methods}

Serum creatine kinase activity was measured using a kinetic ultraviolet NADPH-linked assay with $\mathrm{N}$-acetyl-cysteine as the activator. The recommended Scandinavian optimal procedure was followed. ${ }^{2}$ Reagents were purchased from Merck Sharpe and Dome, in kit form, for use on the ERIS analyser, which operates at a single assay temperature of $37^{\circ} \mathrm{C}$. The results presented are expressed in IU/1 at $25^{\circ} \mathrm{C}$ in accordance with local practice. (This permits continued use of reference ranges applicable to previous instrumentation and reaction conditions. The correction factor is based on correlation studies between two instuments and is expressed by the equation: $y=0.59 x-19$, where $x$ represents output from the ERIS and $y$ the converted result in IU/1 at $25^{\circ} \mathrm{C}$ ). The coefficient of variation (CV) for the method was $5 \%$. Confidence limits of $95 \%$ may be expressed in terms of $\mathrm{CV}$ as $+/-10 \%$. The method is linear to 1000 IU/l. Samples with greater activity were appropriately diluted. The reference range at $25^{\circ} \mathrm{C}$ in a healthy caucasian population is $10-70 \mathrm{IU} / 1$ for women and $10-80 \mathrm{IU} / 1$ for men. ${ }^{2}$

None of the patients studied was clinically hypothyroid, acromegalic, hypokalaemic, hypocalcaemic, alcoholic, or had a personal or family history of muscular dystrophies, any of which may be associated 
Table 1 Details of all patients studied

\begin{tabular}{|c|c|c|c|c|c|c|c|c|}
\hline \multirow[b]{2}{*}{ State } & \multirow[b]{2}{*}{$\operatorname{Sex}$} & \multirow{2}{*}{$\begin{array}{l}\text { Number } \\
\text { studied }\end{array}$} & \multicolumn{2}{|l|}{ Age } & \multicolumn{4}{|c|}{ Genotypes } \\
\hline & & & Mean & (Range) & $S S$ & $S C$ & Sbetat & SD \\
\hline Steady state & $\begin{array}{l}\mathbf{M} \\
\mathbf{F}\end{array}$ & $\begin{array}{l}14 \\
14\end{array}$ & $\begin{array}{l}26 \cdot 5 \\
24\end{array}$ & $\begin{array}{l}(16-34) \\
(16-32)\end{array}$ & $\begin{array}{l}10 \\
11\end{array}$ & $\begin{array}{l}1 \\
3\end{array}$ & 3 & \\
\hline Crises with muscular pain & $\begin{array}{l}\mathbf{M} \\
\mathbf{F}\end{array}$ & $\begin{array}{r}14 \\
3\end{array}$ & $\begin{array}{l}20 \cdot 6 \\
15\end{array}$ & $\begin{array}{l}(14-26) \\
(15-16)\end{array}$ & $\begin{array}{r}10 \\
3\end{array}$ & 2 & 2 & \\
\hline Sequential vaso-occlusive crises studied & $\begin{array}{l}\mathbf{M} \\
\mathbf{F}\end{array}$ & $\begin{array}{l}9 \\
5\end{array}$ & $\begin{array}{l}24 \cdot 8 \\
20 \cdot 6\end{array}$ & $\begin{array}{l}(18-27) \\
(17-28)\end{array}$ & $\begin{array}{l}8 \\
3\end{array}$ & $\begin{array}{l}1 \\
1\end{array}$ & & 1 \\
\hline
\end{tabular}

with increased creatine kinase activity. All patient details are shown in table 1.

\section{STEADY STATE}

Creatine kinase activity was measured in 14 men and 14 women in the steady state attending the Central Middlesex haemoglobinopathy clinic. They had not received any intramuscular injections or blood transfusions in the preceding three months and were leading normal lives.

\section{ASSESSMENT OF VASO-OCCLUSIVE CRISES}

\section{With muscle pain:}

Creatine kinase activity was measured in any patient admitted with a vaso-occlusive sickle cell crisis between March 1984 and May 1987, who had pain in any of the large muscle groups (shoulders, thighs, or buttocks). These patients were treated in the standard way $^{3}$ with intramuscular pethidine "on demand" up to $100 \mathrm{mg}$ hourly.

\section{Consecutive admissions:}

Blood samples were collected daily between 9 and 10 am for creatine kinase activity from 12 patients consecutively admitted with 14 sickle cell crises presenting over two months, regardless of the site of their pain. These patients received no intramuscular injections but received continuous subcutaneous analgesia.

\section{Results}

The mean creatine kinase activity in 28 patients in the steady state was 19.7 (SD 10.8), range $4-45 \mathrm{IU} / 1$ for both men and women. The normal range for a caucasian population is $10-80 \mathrm{IU} / 1$.

The figure shows the results of creatine kinase activity in 17 patients with vaso-occlusive crises and muscle pain. All the patients originally complained of pain in one or more of their large muscle groups and had tenderness of the affected muscles. The mean creatine kinase activity found was $578.8 \mathrm{IU} / \mathrm{l}$ in men and $210.6 \mathrm{IU} / 1$ in women. Six patients attained a creatine kinase activity greater than that usually associated with injection-that is, greater than five to eight times the upper limit of normal ${ }^{4}$ - and details of these are shown in table 2 . Notably, they were all men and included those who had exercised before admission.

Table 3 shows the details of the 14 crises in 10 patients with consecutive sickle cell crises. During crises in which patients had no muscle pain, creatine kinase activity remained within the normal range. Creatine kinase activity was increased in four crises; the highest value was over $2400 \mathrm{IU} / 1$ in a young man (case 4) who developed a chest syndrome after presenting with muscle pain in the shoulders and arms. He

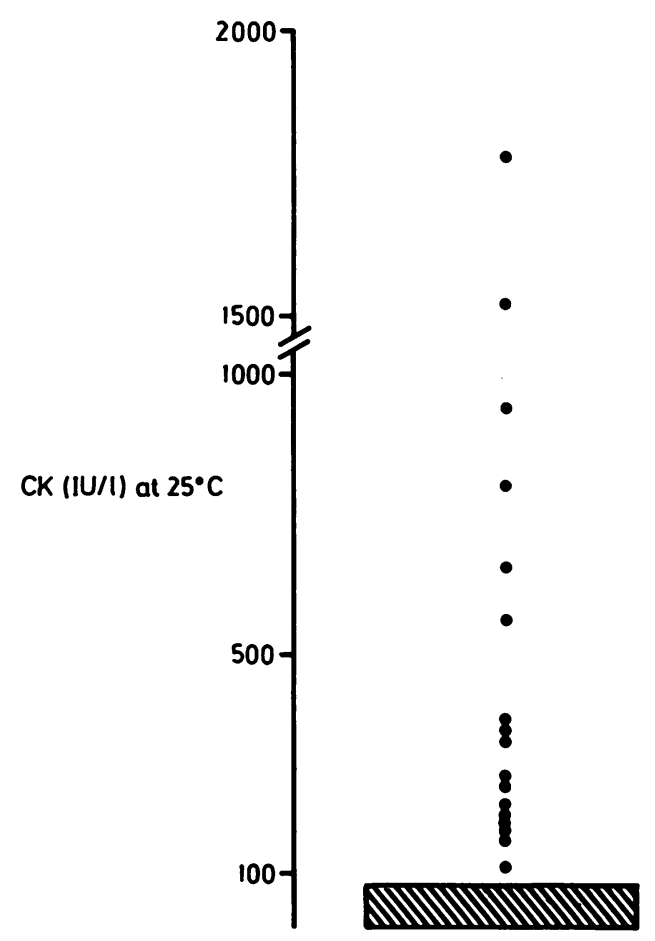

Figure Creatine kinase activity in 17 patients with vaso-occlusive crises and muscle pain. 
Table 2 Patients in whom creatine kinase activity was greater than 500 IU/l

\begin{tabular}{|c|c|c|c|c|c|}
\hline Patient & $\begin{array}{l}\text { Haemoglobinopathy } \\
\text { type }\end{array}$ & $\begin{array}{l}\text { Physical activity in the } \\
\text { day before admission }\end{array}$ & Main site of pain & $\begin{array}{l}\text { Creatine kinase activity } \\
\text { on day of stay }\end{array}$ & $\begin{array}{l}\text { Length of admission } \\
\text { (days) }\end{array}$ \\
\hline $\begin{array}{l}23 \mathrm{M} \\
25 \mathrm{M}\end{array}$ & $\begin{array}{l}\text { SC } \\
\text { SC }\end{array}$ & $\begin{array}{l}\text { Weight-lifting } \\
\text { Played badminton } \\
12 \mathrm{~h} \text { before }\end{array}$ & $\begin{array}{l}\text { Chest wall } \\
\text { *Thighs and buttocks }\end{array}$ & $\begin{array}{l}935 \text { on day } 3 \\
795 \text { on day } 1\end{array}$ & $\begin{array}{l}5 \\
4\end{array}$ \\
\hline $23 \mathrm{M}$ & $\mathbf{S B}+$ & Weight-lifting & $\begin{array}{l}\text { Buttocks, thighs, } \\
\text { and calves }\end{array}$ & 1790 on day 3 & 9 \\
\hline $\begin{array}{l}26 \mathrm{M} \\
22 \mathrm{M} \\
18 \mathrm{M}\end{array}$ & $\begin{array}{l}\text { SS } \\
\text { SS } \\
\text { SS }\end{array}$ & $\begin{array}{l}\text { Nil } \\
\text { Nil } \\
\text { Nil }\end{array}$ & $\begin{array}{l}\text { *Chest and back } \\
\text { Thighs } \\
\text { *Thighs }\end{array}$ & $\begin{array}{r}566 \text { on day } 2 \\
655 \text { on day } 5 \\
1510 \text { on day } 1\end{array}$ & $\begin{array}{r}8 \\
8 \\
12\end{array}$ \\
\hline
\end{tabular}

* Swelling of muscle groups involved.

required exchange transfusion on day 3 . The other two patients who had a chest syndrome with chest wall and back pain and required exchange transfusion showed a marginal increase in creatine kinase activity on the day of admission. A temporary rise in creatine kinase activity was seen in cases 1 and 2 whose main site of pain was in the thighs, and in case 3 who had pain in the thighs and abdomen. In those patients with a rise in creatine kinase activity above normal the zenith was reached on days 1 or 2 .

\section{Discussion}

This study has shown that in the steady state of sickle cell disease creatine kinase activity is within normal limits, but in some sickle cell crises, especially where muscle bulk is affected, creatine kinase activity is increased above the concentrations associated with intramuscular injections. ${ }^{4}$

Creatine kinase activity is a sensitive indicator of recent muscle membrane pertubation, rising within

Table 3 Serial creatine kinase activity in 14 consecutive crises

\begin{tabular}{|c|c|c|c|c|c|c|c|}
\hline \multirow{2}{*}{$\begin{array}{l}\text { Case number } \\
\text { age/sex/haemo- } \\
\quad \text { globinopathy }\end{array}$} & \multicolumn{7}{|c|}{$\begin{array}{l}\text { Creatine kinase activity (IU/l) } \\
\text { Days of admission }\end{array}$} \\
\hline & 1 & 3 & 5 & 6 & 7 & 8 & 9 \\
\hline \begin{tabular}{ll}
\multicolumn{3}{c}{ Patients with muscle p } \\
1 & $27 \mathrm{M} \mathrm{SC}$ \\
2 & $27 \mathrm{M} S$ \\
3 & $26 \mathrm{M} S$ \\
&
\end{tabular} & $\begin{array}{rl}\text { pain: } & \\
218 & 531 \\
399 & 388 \\
53 & 295\end{array}$ & $\begin{array}{r}280 \\
36\end{array}$ & 141 & 170 & & & 28 \\
\hline $\begin{array}{ll}\text { Patients with chest syn } \\
2 & 27 \mathrm{M} \mathrm{SS} \\
4 & 26 \mathrm{M} S \\
5 & 18 \mathrm{M} S \\
& \end{array}$ & $\begin{array}{l}\text { indromes: } \\
5032435 \\
\begin{array}{ll}139 & 83^{*} \\
146 & 7^{*}\end{array}\end{array}$ & $\begin{array}{r}1460 \\
12 \\
+\quad 55\end{array}$ & $\begin{array}{c}59^{*} \\
6\end{array}$ & 9 & & & \\
\hline 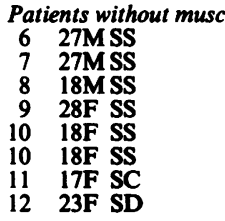 & $\begin{array}{cc}\text { cle pain: } & \\
28 & 22 \\
39 & 13 \\
\frac{13}{33} & 13^{*} \\
& <10 \\
& <10 \\
83 & 33 \\
14 & <10 \\
<10 & 17\end{array}$ & $\begin{array}{r}49 \\
2 \\
26 \\
26 \\
<10 \\
<10 \\
2 \\
<10 \\
<10<\end{array}$ & $\begin{array}{r}14 \\
<10< \\
15< \\
<10<\end{array}$ & $\begin{array}{l}<10 \\
<10<\end{array}$ & $10<1$ & & \\
\hline
\end{tabular}

*The patient was exchange transfused for a chest and/or abdominal crisis. two to three hours after insult. Creatine kinase comprises three separate isoenzymes in the body, but MM isoenzyme (from skeletal muscles) accounts for nearly all normal serum activity, together with a trace of MB (from cardiac muscles). We had no reason to believe that there was cardiac or cerebral disease in any of the crises studied, so we assumed that any rise in creatine kinase activity in the patients with sickle cell disease reflected increased activities of the skeletal muscle isoenzyme MM.

The amount of creatine kinase activity depends on age, sex, and race. ${ }^{5}$ Activities in adolescents are higher than in adults, while the reference range for women at all ages is lower than for men, presumably due to their smaller muscle mass. Previous studies of American negro populations have shown higher mean creatine kinase activities compared with those of caucasians. ${ }^{5}$ Gledhill et al suggested that these differences could be explained by different levels of exercise or a genetic difference in response to exercise or both. ${ }^{6}$ The low activities seen in our patients of Afro-Caribbean origin in the steady state of sickle cell disease compared with the normal range of the caucasian population are thus surprising. Possibly, they may reflect a lower level of physical activity or decreased muscle bulk-for most patients with sickle cell disease have an asthenic build. A constant low level of muscle membrane pertubation due to subclinical sickling was not confirmed by any increase in creatine kinase activity. There are several non-pathological reasons for increased creatine kinase activity. Creatine kinase activities up to five to eight times the upper limit of normal may occur after intramuscular injections in normal subjects ${ }^{4}$; factors such as volume, osmolarity, and type of substance injected will affect the rise in creatine kinase activity. Aware of these factors, we measured creatine kinase activity in patients with vaso-occlusive crises receiving only subcutaneous not intramuscular injections and showed large increases in creatine kinase activity during crises in which muscles were affected.

After severe exercise healthy people can attain high creatine kinase activity over $1000 \mathrm{IU} / 1$ after 45 minutes of exercise, ${ }^{7}$ reaching a peak up to 24 hours after exercise; creatine kinase activity may remain increased 
for up to 72 hours. Increased creatine kinase activities in our patients during sickle cell crises showed a similar pattern. Heavy exercise, especially weight-lifting (which has been shown to cause rhabdomyolysis in normal subjects ${ }^{8}$ ), preceded admission of three of our patients with vaso-occlusive crises involving muscular bulk. This is consistent with Diggs's hypothesis that strenuous exercise may be a precipitating factor for some vaso-occlusive crises. ${ }^{9}$ This would not be entirely unexpected; in vitro studies ${ }^{1011}$ have shown that intramuscular $\mathrm{pH}$ and oxygen partial pressure during exercise are low enough to cause sickle haemoglobin polymerisation, even in sickle cell trait. This may result in irreversibly sickled cells occluding arterioles in the muscles with consequent ischaemia and pain. There have been reports of rhabdomyolysis, renal failure, and disseminated intravascular coagulation causing deaths in people with sickle cell trait after strenuous exercise. $^{12}$

Interestingly, all the patients with increased creatine kinase activity were men and a disproportionate number of patients with sickle cell disease or $\beta$ thalassemia had crises affecting muscle bulk after exercise. Perhaps this is due to their lower grade of anaemia which allows them to exercise.

In conclusion, creatine kinase activity is a sensitive indicator of muscular compromise in sickle cell crises. There is a suggestion that exercise is a precipitating factor in vaso-occlusive crises which affect muscles. Creatine kinase activity should be measured in patients in sickle cell crisis with painful or swollen muscles as the muscle damage may be sufficiently severe to cause rhabomyolysis and subsequent renal damage. Further studies of creatine kinase activity, including the effect of isoenzymes are needed to assess the importance of increased creatine kinase activity in vaso-occlusive crises and also to look at other indicators of rhabdomyolysis.

\section{References}

1 Devereux S, Knowles SM. Rhabdomyolysis and acute renal failure in sickle cell anaemia. $\mathrm{Br}$ Med J 1985;290:1707.

2 Committee on Enzymes of The Scandinavian Society for Clinical Chemistry and Clinical Physiology. Recommended method for the determination of creatine kinase in blood. Scand J Clin Lab Invest 1976;36:711-21.

3 Brozovic M, Davies S. Management of sickle cell disease. Postgrad Med J 1987;63:605-9.

4 Rosalki SB. The principles and practice of diagnostic enzymology. London: Edward Arnold, 1976:263-302.

5 Black HR, Quallich BA, Gareleck CB. Racial differences in serum creatine kinase levels. Am J Med 1986;81:479-87.

6 Gledhill RF, van Niekerk MM, van de Merwe CA. Racial differences in serum creatine kinase levels. Am $\mathrm{J}$ Med 1987;83:365-6.

7 Evans WJ, Meredith CN, Cannon JG. Metabolic changes following eccentric exercise in trained and untrained men. $J$ Appl Physiol 1986;61:1864-7.

8 Bartlett JC, Rooney TW, Hunter JC. Rhabdomyolysis of the upper extremities associated with weight lifting: report of a case. J Am Osteopath Assoc 1985;85:646-8.

9 Diggs LW. Sickle cell crises. Am J Clin Pathol 1965;44:1-19.

10 Hansen JE, Vogel JA, Stelter GP, Consolazio CF. Oxygen uptake in man during exhaustive work at sea level and high altitude. J Appl Physiol 1967;23:511-22.

11 Donald KW, Wormald PJ, Taylor SH, Bishop JM. Changes in the oxygen content of the femoral venous blood and leg blood flow during leg exercise in relation to cardiac output response. Clin Sci 1957; 16:567-91.

12 Charache S. Sudden death in sickle trait. Am J Med 1988;84: 459-61.

Requests for reprints to: Dr B J Hunt, Department of Immunology, Harefield Hospital, Harefield, Middlesex UB9 6JR, England. 